\title{
AGE ESTIMATES FOR SOME SUBTERRANEAN TAXA AND LINEAGES IN THE DINARIC KARST
}

\section{OCENE STAROSTI ZA NEKATERE PODZEMELJSKE TAKSONE IN ŽIVALSKE LINIJE NA DINARSKEM KRASU}

\author{
Peter TRONTELJ ${ }^{1}$, Špela GORIČKI ${ }^{1}$, Slavko POLAK ${ }^{2}$, Rudi VEROVNIK ${ }^{1}$, \\ Valerija ZAKŠEK ${ }^{1} \&$ Boris SKET ${ }^{1}$
}

\begin{abstract}
UDC 575.8:551.442(234.422.1)
$591.542(234.422 .1)$

Peter Trontelj, Špela Gorički, Slavko Polak, Rudi Verovnik, Valerija Zakšek \& Boris Sket: Age estimates for some subterranean taxa and lineages in the Dinaric Karst

Using a comparative phylogeographic approach and different independent molecular clocks we propose a timescale for the evolution of troglobionts in the Dinaric Karst that is relatively consistent over a wide taxonomic range. Keystone events seem to belong to two age classes. (1) Major splits within holodinaric taxa are from the mid-Miocene. They present the potential upper limit for the age of cave invasions. (2) Regional differentiation, including speciation, which can at least in part be associated with a subterranean phase, took place from early Pliocene to mid-Pleistocene. We suggest two to five million years as the time when most of the analyzed lineages started invading the Dinaric Karst underground.
\end{abstract}

Key words: subterranean, molecular clock, molecular phylogeny, phylogeography, Dinaric Karst.
Izvleček

UDK 575.8:551.442(234.422.1)

$591.542(234.422 .1)$

Peter Trontelj, Špela Gorički, Slavko Polak, Rudi Verovnik, Valerija Zakšek \& Boris Sket: Ocene starosti za nekatere podzemeljske taksone in živalske linije na Dinarskem krasu

$\mathrm{Z}$ uporabo primerjalnega filogeografskega pristopa in neodvisnih molekularnih ur smo predlagali časovni potek evolucije troglobiontov Dinarskega krasa, ki velja za sorazmerno veliko število taksonov. Zdi se, da ključni dogodki pripadajo dvema obdobjema. (1) Glavne razdelitve znotraj holodinarskih taksonov so iz obdobje srednjega miocena. Predstavljajo zgornji potencialni časovni limit za naselitev jam. (2) Regionalna diferenciacija, vključno s speciacijo, ki je lahko vsaj deloma povezana s podzemeljsko fazo, naj bi se zgodila med zgodnjim in srednjim pleistocenom. Ocenjujemo, da se je začela invazija večine proučevanih živalskih linij v podzemlje Dinarskega krasa v obdobju med dvema in petimi milijoni let.

Ključne besede: podzemlje, molekularna ura, molekularna filogenija, filogeografija, Dinarski kras.

\section{INTRODUCTION}

The use of new molecular and systematic techniques using allozymes and DNA sequences has enabled us to see a new picture of the evolution and diversity of subterranean fauna (e.g. Avise \& Selander 1972; Sbordoni et al., 2000; Caccone \& Sbordoni 2001; Leys et al., 2003; Verovnik et al., 2004; Gorički \& Trontelj 2006; Lefébure et al., 2006; Zakšek et al., 2007). Molecular clock ap- proaches should, at least in theory, enable us to date, to verify or to falsify previous hypotheses about the age of subterranean species. To be exact, it is usually not the age of a lineage or a taxon itself that is of special interest or under dispute, but the time since it has attained its subterranean nature, making it even more challenging. Hypotheses and models explaining cave invasions

\footnotetext{
${ }^{1}$ Oddelek za biologijo, Biotehniška fakulteta, Univerza v Ljubljani, Večna pot 111, 1000 Ljubljana, Slovenia, fax: +386 12573390 , e-mail: peter.trontelj@bf.uni-lj.si

${ }^{2}$ Notranjski muzej Postojna, Ljubljanska 10, 6230 Postojna, Slovenia.

Received/Prejeto: 30.01.2007
} 
and speciation in caves are well-elaborated (e.g. Rouch \& Danielopol 1987; Holsinger 2000; Trajano 2005) and should thus offer good grounds for the timing of such events and for testing their correlation with geographical, geological and hydrographical counterparts. For example, Leys et al., (2003) have shown that all evolutionary transitions to subterranean life in Australian dytiscids took place during the Late Miocene and Early Pliocene as a result of aridification. However, reliable data on the age of these events is surprisingly scarce. When such data are available, the accuracy is often below that of molecular clock rates. In fact, the use of molecular dating methods itself has introduced considerable uncertainty about how old subterranean species might be. While the youngest estimation, based on "classical" biological reasoning, is no more than 10,000 years (Sket 1997), the upper limit for the divergence of two subterranean sister species has been pushed to an incredible 110,000,000 years (Buhay \& Crandall 2005).

Boutin and Coineau (2000) have argued that dating of cladogenetic events by a molecular clock is particular- ly useful in the case when the dates are corroborated by other methods. Since the obvious problem of the Dinaric Karst area is that reliable dating for clearly defined vicariant events or the age of available subterranean habitat is lacking, it has been impossible to corroborate molecular clock divergence by independent data. In this case a comparative phylogeographic approach might provide the means for an independent validation of age estimates. Comparative phylogeography seeks, as does historical biogeography, concordant geographical patterns of codistributed lineages (e.g. Arbogast \& Kenagy 2001). The evolution of codistributed phylogeographic groups of different taxa is likely to have been driven by the same historical factors, like vicariant events or climatic shifts.

In this contribution we (1) identify common phylogeographic patterns among those troglobiotic taxa from the Dinaric Karst for which such data are available, and (2) estimate the timeframe of the corresponding cladogenetic events using a global molecular clock approach.

\section{MATERIAL AND METHODS}

The presented data were taken from several phylogeographic studies of subterranean animals in the Dinaric Karst, including the ubiquitous aquatic isopod Asellus aquaticus Linne (Verovnik et al., 2004, 2005), the cave salamander Proteus anguinus Laurenti (Gorički 2006, Gorički \& Trontelj 2006), and the cave shrimp Troglocaris s. lato (Zakšek et al., 2007). Further, we included unpublished sequences from studies that are in progress, including leptodirine cave beetles and aquatic sphaeromatid isopods from the genus Monolistra. The age estimations for the last two groups should be regarded as preliminary because in-depth analyses of phylogenetic relationships and corroboration by further loci are still under way. We were only interested in a small number of well-supported splits and therefore used straightfor- ward minimum evolution searches with bootstrapping as implemented in MEGA (Kumar et al., 2004). Divergence time estimates are based on available clock-rate data for groups that are as closely related as possible (Caccone \& Sbordoni [2001] for leptodirines, Ketmaier et al., [2003] for Asellus aquaticus, and Sturmbauer et al., [1996] and Schubart et al., [1998] for Monolistra). To assure compatibility between molecular divergences we used the same models as were used in the original works describing the rates (Tamura-Nei distances with a gamma distributed rate variation among sites). Where more than one haplotype per population or lineage was analyzed we used net between group distances to correct for ancestral intraspecific diversity.

\section{RESULTS}

The split between major geographically defined lineages

The geographical distribution of troglobiotic (including stygobiotic) sister taxa can be used to infer independent cave invasions. For example, if the present-day ranges of two troglobionts are separated by large areas of non-karstic terrain without hypogean habitat, we can postulate an epigean last common ancestor. Examples of that kind can be found in the shrimp genus Troglocaris, with the Hercegovinensis lineage inhabiting Transcaucasian and SE parts of the Dinaric Karst where it is sympatric with the SE populations of the Anophthalmus lineage (Zakšek et al., 2007). Their split estimated at 6-11 
Myr ago is the oldest, although unlikely, possible time of cave invasion. The youngest split that could be reliably inferred from the phylogenetic tree and probably still occurred in surface waters, was the one between the Bosnian lineage and other "Anophthalmus" lineages. Because the karst area in Bosanska Krajina, to which the Bosnian clade is restricted, is so remote and isolated from the rest of the Dinaric populations, it is reasonable to assume that an underground connection between them could never have existed. The estimated time of this split, $3.7-5.3 \mathrm{Myr}$ ago, is hence the oldest possible age at which Troglocaris anophthalmus might have invaded the Dinaric Karst underground (Tab. 1).

\section{TIMING OF MORPHOLOGICAL CHANGES}

Where possible, we tried to combine the biology (e.g. degree of troglomorphism, lack of gene flow) of taxa with corresponding data on paleogeography and paleohydrography to infer speculative scenarios on how and when lineages might have switched to subterranean life and evolved troglomorphic traits. For example, we have some indication about how long at most it takes a salamander population to become troglomorphic. Since the subspecies $P$. $a$. parkelj Sket et Arntzen has retained its ancestral, non-troglomorphic characteristics, it is reasonable to conclude that its sister lineage must have evolved

Tab. 1. Estimated time (in million years) of some keystone events in the evolution of troglobionts in the Dinaric Karst.

\begin{tabular}{|c|c|c|c|c|}
\hline Taxon & $\begin{array}{l}\text { Age of } \\
\text { holodinaric } \\
\text { group }\end{array}$ & $\begin{array}{l}\text { Age of } \\
\text { merodinaric } \\
\text { group }\end{array}$ & Mid-Dinaric split & Northwest split \\
\hline Troglocaris (Dinaric and Caucasian lineages) ${ }^{1}$ & $7.9-15.1$ & n.a. & n.a. & n.a. \\
\hline Troglocaris anophthalmus agg. ${ }^{1}$ & n.a. & $3.7-5.3$ & $1.3-2.3$ & $1.5-2.1$ \\
\hline Troglocaris hercegovinensis agg. ${ }^{1}$ & n.a. & $3.8-4.8$ & n.a. & n.a. \\
\hline Proteus anguinus ${ }^{2}$ & $8.8-16.0$ & n.a. & $8.8-16.0$ & $4.2-5.2$ \\
\hline Asellus aquaticus (Dinaric clade) ${ }^{3}$ & n.a. & $3.8-4.8$ & n.a. & $0.8-1.2$ \\
\hline Microlistra ${ }^{4}$ & n.a. & $1.1-2.3$ & n.a. & n.a. \\
\hline Pseudomonolistra hercegoviniensis ${ }^{4}$ & n.a. & $0.3-1.0$ & n.a. & n.a. \\
\hline Monolistra caeca ${ }^{4}$ & n.a. & $1.8-3.7$ & n.a. & n.a. \\
\hline $\begin{array}{l}\text { Leptodirus hochenwartii hochenwartii } \\
\text { et L. h. reticulatus }{ }^{5}\end{array}$ & n.a. & $1.9-2.0$ & n.a. & n.a. \\
\hline
\end{tabular}

${ }^{1}$ Using COI clock for shrimps (see Knowlton \& Weigt 1998; Zakšek et al., 2007)

${ }^{2}$ Using $12 S$ and $16 S$ rDNA clock for Newts (see Cacconesee et al., 1997; Gorički 2006)

${ }^{3}$ Using COI clock for subterranean Asellota (see Ketmaier et al., 2003; Verovnik et al 2005)

${ }^{4}$ Using $16 S$ r-RNA clock for fiddler crabs (Sturmbauer et al 1996) and land crabs (Schubart et all 1998)

${ }^{5}$ Using COI clock for subterranean leptodirine beetles (Caccone \& Sbordoni 2001)

For the cave salamander Proteus anguinus, exhibiting a distribution pattern similar to that of Troglocaris, the corresponding age of the Bosanska Krajina lineage was estimated at 4.4-5.4 Myr (Gorički 2006). However, older lineages exist that, theorethically, might have invaded caves even as early as $8.8-16 \mathrm{Myr}$ ago (see also Fig. 1).

Another troglobiotic group restricted to the Dinaric Karst area and having a non-troglomorphic sister group is the Dinaric clade of Asellus aquaticus (see Verovnik et al., 2005). The time of this split, and hence the maximum possible age of cave invasion is 3.8-4.8 Myr. troglomorphoses independently from other, less related troglomorphic lineages (Sket \& Arntzen 1994; Gorički \& Trontelj 2006; see Fig. 1). The split between the nontroglomorphic lineage and its last troglomorphic sister lineage was estimated at $0.5-0.6 \mathrm{Myr}$ based on mitochondrial rDNA sequences, 1.1-2.4 Myr based on the mtDNA control region (Gorički 2006), and at 1.1-4.5 Myr by an allozyme clock (Sket \& Arntzen 1994).

Asellus aquaticus has evolved several separate subterranean and troglomorphic populations. One of them, from the subterranean Reka River below the Kras/Carso Plateau, is genetically completely isolated from epigean populations at the Reka resurgence while there are no epigean populations in the Reka before the sink (Verovnik et al., 2003, 2004, 2005; Fig. 2). Further, it has no mtDNA 


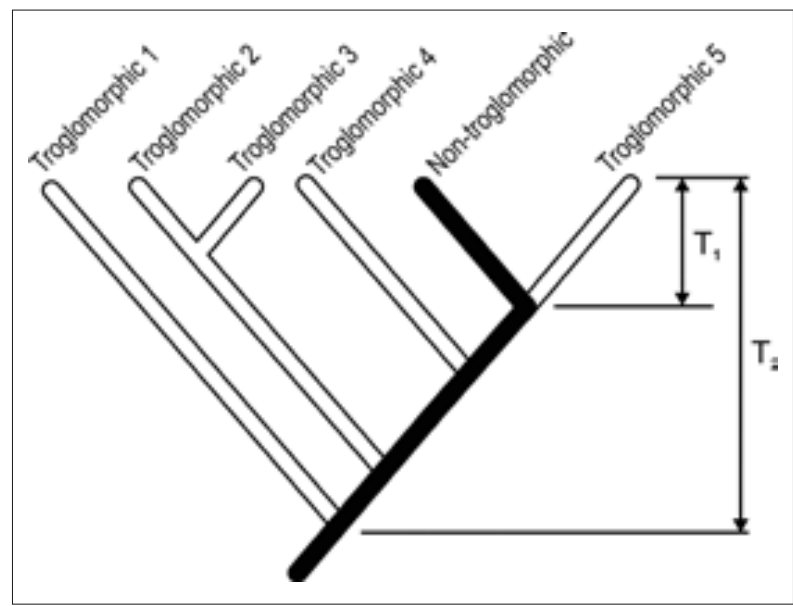

Fig. 1: A simplified view of the phylogenetic relationships obetween troglomorphic and non-troglomorphic Proteus anguinus populations (from Gorički and Trontelj 2006). Postulating a non-troglomorphic ancestor and unidirectional evolution toward troglomorphism, we can take the split between the black subspecies (non-troglomorphic) and its unpigmented sister lineage to estimate the maximal time (T1) needed for a salamander lineage to evolve the entire array of cave-related traits known in this taxon. If one accepts the notion of multiple independent cave invasions for Proteus, than T2 is the potentially oldest time since it has become subterranean.

and nuclear rDNA haplotypes in common with hypogean populations from the Ljubljanica River drainage with which the Reka drainage has been connected many times during the Pleistocene and occasionally even nowadays (Habič 1989). It is thus reasonable to assume that the ancestor of the subterranean Reka River population invaded hypogean waters and became cave-adapted before any secondary contact could occur. The estimated age of the Reka River lineage is 3.1-4.1 Myr (Verovnik et al., 2004), making it a pre-Pleistocene troglobiotic relict (Verovnik et al., 2004).

Monolistra, a troglobiotic group of freshawater sphaeromatid isopods, shows a high taxonomic and morphological diversity restricted to the Dinaric Karst and parts of the Southern Calcareous Alps. According to our preliminary results of a molecular phylogenetic analysis based on nuclear and mitochondrial DNA sequences, there are at least three well-supported monophyla. These are the subgenus M. (Microlistra), M. (Monolistra) caeca Gerstaecker, and the polytypic M. (Pseudomonolistra) hercegoviniensis Absolon. Several lines of evidence suggest that the common ancestors of each of these groups invaded cave waters polytopically (Sket 1986, 1994). While we remain ignorant about when and how often ancestral Monolistra lineages invaded subterranean waters, we can expect that the radiation of at least some of the three groups took place in the underground. Their ages

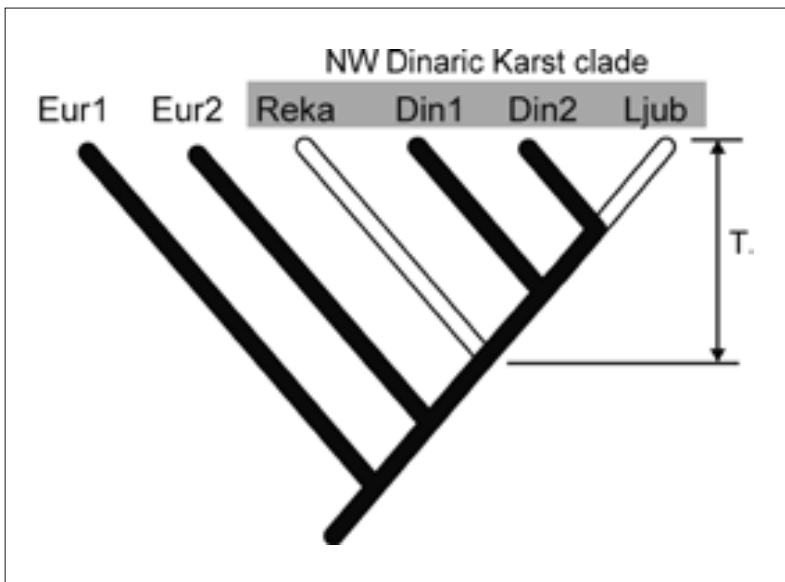

Fig. 2: The case of troglomorphic and non-troglomorphic lineages of Asellus aquaticus in the Dinaric Karst, highly simplified (from Verovnik et al 2004, 2005). The Reka and the Ljubljanica (Ljub) basin lineages have independently invaded subterranean waters and thus constitute separate taxa, although traditionally assigned to the same subspecies, A. a. cavernicolus. The subterranean Reka River population presents the oldest stygobiotic lineage of Asellus aquaticus. Because it is genetically completely distinct, it must have escaped interbreeding during various times of hydrological contact with surface populations. We therefore believe that it became a specialized stygobiont soon after the split at time T1. The Ljub lineage from the subterranean Ljubljanica River, although morphologically distinct, is still sharing mtDNA haplotypes with surface populations and thus represents a younger invasion. Eur and Din denote various epigean European and Dinaric lineages, respectively.

(maximally 0.4-3.7 Myr) give us an idea for how long some Monolistra lineages have been dwelling in the Dinaric Karst underground.

Leptodirus hochenwartii Schmidt, a highly troglomorphic leptodirine cave beetle, is the only terrestrial Dinaric troglobiont with available molecular dating. Using a leptodirine COI clock calibration by Caccone and Sbordoni (2001) we estimated the age of the Leptodirus lineage by dating the split with Astagobius angustatus Schmidt, its slightly less troglomorphic sister lineage. The estimated time of this split (8.7-9.8 Myr ago) is the oldest possible age at which the extremely specialized morphology of Leptodirus could have started evolving. Moreover, taking into account recent unpublished phylogenetic findings based on nuclear and mitochondrial gene sequences, the traditional subspecies of Leptodirus in fact represent distinct lineages with divergences well in the range of between species comparisons. These lineages all share the same constructive apomorphic troglomorphic characters, and it seems probable these troglomorphies have already existed at least at the time of their last common ancestor. The time of divergence between basal Leptodirus lineages hence represents the youngest possible age at which Leptodirus has evolved its full array 
of troglomorphic characters. Based on a yet incomplete taxonomic sample ( $L$. h. hochenwartii Schmidt and $L$. h. reticulatus J. Müller) we tentatively dated it at $1.9-2.0$ Mya.

\section{TIMING OF PALEOHYDROGRAPHIC CHANGES}

For some stygobiotic taxa with a broader Dinaric range, we identified two concordant geographic patterns possibly pointing to common underlying historical events, like changes in hydrographic connections. These vicariant patterns include (1) a split between a northwestern and southeastern Dinaric clade (mid-Dinaric split), and (2) a younger subdivision of the northwestern clade (or of a part thereof) into a western and eastern Slovenian lineage (Tab. 1).

It has been stated that some stygobiotic species inhabit areas that are hydrographically fragmented. The most parsimonious explanation of such distributions is that their ranges were hydrographically interconnected in the past. This may as well include the surface paleohydrography that was heavily fragmented by karstification. The (polytopic) immigration underground could thus have proceeded simultaneously with the separation of ancestral populations. We can illustrate this scenario by the case of some Monolistra lineages, namely of the subgenus Microlistra and of the species M. (M.) caeca. Some ten Microlistra spp. are perfectly allopatric in distribution, mainly bound to actual watersheds. Another group, $M$. caeca, inhabits at least three watersheds, in which four named subspecies have evolved. According to a $16 \mathrm{~S}$ rDNA molecular clock (Sturmbauer et al., 1996, Schubart et al., 1998), the system began to fragment about three million years ago.

\section{DISCUSSION}

Before we reach any conclusions we would like to note that dating of keystone events in the evolution of subterranean life, as well as anywhere else in evolution (e.g. Graur \& Martin 2004), remains a highly speculative enterprise. Of central concern should be the fact that we are relying on a more or less global clock within certain taxonomic boundaries. These clocks usually rely on single calibration points (e.g. the separation of the SardiniaCorsica microplate from the Iberian Peninsula; Ketmaier et al., 2003) and have mostly not been tested against independent geological events.

Further, all our timings assume linear accumulation of substitutions over time, i.e. the existence of a valid molecular clock. Although we can be quite sure that this assumption is violated to a certain extent, we can mitigate the problem by excluding those taxa from the analysis that violate the linearity assumption most. More sophisticated and realistically modeled approaches use a relaxed clock allowing for different local rates on different branches of the tree (e.g. Sanderson 2002). However, with single calibration points only, such approaches yield quite hopeless and certainly unrealistic intervals. For example, the age of the deepest split in the Niphargus virei (subterranean amphipod from France) complex was estimated at 14-19 Myr using a global Stenasellus clock, whereas the relaxed clock estimate was 22-71 Myr (Lefébure et al., 2006).

Third, it should be noted that even with the aid of molecular phylogenetic tools the timing is still susceptible to incorrect estimations of relationships and incomplete taxonomic coverage. For example, the timing of the origin of the highly troglomorphic morphologies in Leptodirus depends on the most basal split in the taxon. By not having included all known subspecies, we are facing the risk that some other subspecies might have branched off earlier than the studied ones.

One potentially useful way to improve our informal confidence in the timing of evolutionary events in subterranean animals is to look for phylogeographic correspondence of timings derived from independent taxa with independent molecular clocks. At the present stage of most of our analyses such comparisons can only be preliminary. We can nevertheless notice that specific groups of events belong to different age classes, most markedly the gap between the age of holodinaric troglobionts and those with narrower distributions within the Dinaric Karst (Tab. 1). The recent lineages of Proteus and Troglocaris probably both originate from the Miocene Dinaride Lake System (Krstić et al., 2003), and the age of both taxa reflects their differentiation long before they invaded the hypogean environment (Sket 1997; Gorički 2006; Zakšek et al., 2007). Regional differentiation, including speciation, which can at least in part be associated with a subterranean phase, appears to be much younger, ranging from Pliocene to mid-Pleistocene. Based on these estimates plus the estimated age of the Reka River lineage of Asellus aquaticus (see above) we, tentatively, suggest two to five million years as the time when most of the analyzed lineages started invading the Dinaric Karst underground.

The mid-Dinaric split of Proteus and Troglocaris anopthalmus does not seem to originate from the same 
vicariant event as the latter was estimated to be younger by an order of magnitude. Another commonality of the phylogeographic pattern, the division between a western and an eastern clade in the Slovenian Dinaric Karst, might have a common hydrogeological cause in two stygobiotic crustaceans (A. aquaticus and T. anophthalmus) somewhere in the middle of the Pleistocene. In Proteus, however, the same split appears to be substantially older.

In the Dinaric Karst we were, so far, unable to find reliable time estimates for paleogeographic events to calibrate local molecular clocks in different lineages. Con- versely, the timing of phylogenetic events can serve, inasmuch as we rely on global molecular clocks, to estimate the date of geographical, hydrographical, and geological changes (Sket 2002). The comparative phylogeographic approach and the use of different independent molecular clocks have enabled us for the first time to propose a timescale for the evolution of troglobionts that is relatively consistent over a wide taxonomic range. This timescale is a preliminary one, though. We expect it to change with the inclusion of further taxa, the study of more genes and the use of more accurate molecular dating approaches.

\section{ACKNOWLEDGMENTS}

We are indebted to many friends and colleagues who helped us with the acquisition of biological samples and accompanied us during field work. We thank Gregor Bračko and Jožica Murko-Bulič for their indispensable assistance in the lab. The presented work is the result of several research projects funded by the Slovenian Research Agency, and of the contract $n^{\circ}$ EVK2-CT-200100121- PASCALIS of the Fifth Research and Technological Development Framework Program supported by the European Community

\section{REFERENCES}

Arbogast, B.S. \& Kenagy, G.J., 2001: Comparative phylogeography as an integrative approach to historical biogeography.- Journal of Biogeography, 28, 819-825.

Avise, J.C. \& Selander, R.K., 1972: Evolutionary genetics of cave dwelling fishes of the genus Astyanax.- Evolution, 26, 1-19.

Boutin, C. \& Coineau, N., 2000: Evolutionary rates and phylogenetic age of some stygobiontic species. In: Subterranean ecosystems - Ecosystems of the World 30 (Eds. H. Wilkens, D.C. Culver \& W.F. Humphreys).- Elsevier, Amsterdam etc., pp. 433-451.

Buhay, J.E. \& Crandall, K.A., 2005: Subterranean phylogeography of freshwater crayfishes shows extensive gene flow and surprisingly large population sizes.Molecular Ecology, 14, 4259-4273.

Caccone, A., Milinkovitch, M.C., Sbordoni, V. \& Powell, J.R., 1997: Mitochondrial DNA rates and biogeography in European newts (genus Euproctus).- Systematic Biology, 46, 126-144.

Caccone, A. \& Sbordoni, V., 2001: Molecular biogeography of cave life: a study using mitochondrial DNA from bathysciine beetles.- Evolution, 55, 122-130.
Gorički, Š. \& Trontelj, P., 2006: Structure and evolution of the mitochondrial control region and flanking sequences in the European cave salamander Proteus anguinus.- Gene, 387, 31-41.

Gorički, Š., 2006: Phylogeographic and morphological analysis of European cave salamander (Proteus anguinus) populations. Doctoral Dissertation.- University of Ljubljana, Biotechnical Faculty, Dept. of Biology, Ljubljana.

Graur, D. \& Martin, W., 2004: Reading the entrails of chickens: molecular timescales of evolution and the illusion of precision.- Trends in Genetics, 20, $80-86$.

Habič, P., 1989: Kraška bifurkacija Pivke na jadransko črnomorskem razvodju (Pivka carst bifurcation on Adriatic - Black Sea watershed).- Acta Carsologica, $18,233-264$.

Holsinger, J.R., 2000: Ecological derivation, colonization, and speciation. In: Subterranean ecosystems - Ecosystems of the World 30 (Eds. H. Wilkens, D.C. Culver \& W.F. Humphreys).- Elsevier, Amsterdam etc., pp. 399-415. 
Ketmaier, V., Argano, R. \& Caccone., A., 2003: Phylogeography and molecular rates of subterranean aquatic Stenasellid Isopods with a peri-Thyrrenian distribution.- Molecular Ecology, 12, 547-555.

Knowlton, N. \& Weigt, L.A., 1998: New dates and new rates for divergence across the Isthmus of Panama.Proceedings of the Royal Society of London B, 265, 2257-2263.

Krstić, N., Savić, L., Jovanović G. \& Bodor, E., 2003: Lower Miocene lakes of the Balkan Land. Acta Geologica Hungarica, 46/3, 291-299.

Kumar, S., Tamura, K \& Nei M., 2004: MEGA3: Integrated software for Molecular Evolutionary Genetics Analysis and sequence alignment.- Briefings in Bioinformatics, 5, 150-163.

Lefébure, T., Douady, C.J., Gouy, M., Trontelj, P., Briolay, J. \& Gibert, J., 2006: Phylogeography of a subterranean amphipod reveals cryptic diversity and dynamic evolution in extreme environments.- Molecular Ecology, 15, 1797-1806.

Leys, R., Watts, C.H.S., Cooper, S.J.B. \& Humphreys, W.F., 2003: Evolution of subterranean diving beetles (Coleoptera: Dytiscidae: Hydroporini, Bidessini) in the arid zone of Australia.- Evolution, 57, 2819-2834.

Rouch, R. \& Danielopol, D. L., 1987: L’origine de la faune aquatique souterraine, entre le paradigme du refuge et le modele de la colonisation active.- Stygologia, 3, 345-372.

Sanderson, M.J., 2002: Estimating absolute rates of molecular evolution and divergence times: a penalized likelihood approach.- Molecular Biology and Evolution, 19, 101-109.

Sbordoni, V., Allegrucci, G. \& Cesaroni, D., 2000: Population genetic structure, speciation and evolutionary rates in cave-dwelling organisms. In: Subterranean ecosystems - Ecosystems of the World 30 (Eds. H. Wilkens, D.C. Culver \& W.F. Humphreys).- Elsevier, Amsterdam etc., pp. 453-477.

Schubart, C.D., Diesel, R. \& Hedges, S.B., 1998: Rapid evolution to terrestrial life in Jamaican crabs.- Nature, 393, 363-365.

Sket, B., 1986: Evaluation of some taxonomically, zoogeographically, or ecologically interesting finds in the hypogean waters of Yugoslavia (in the last decades). Comunicaciones, 9. Congreso Internacional de Espeleologia, 1, 126-128.
Sket, B., 1997: Distribution of Proteus (Amphibia: Urodela: Proteidae) and its possible explanation.- Journal of Biogeography, 24, 263-280.

Sket, B., 2002: The evolution of the karst versus the distribution and diversity of the hypogean fauna. In: Evolution of karst: from Prekarst to cessation (Ed. F. Gabrovšek)- Ljubljana-Postojna, pp. 225-232.

Sket, B. \& Arntzen, J.W., 1994: A black, non-troglomorphic amphibian from the karst of Slovenia: Proteus anguinus parkelj n. ssp. (Urodela: Proteidae).- Contributions to Zoology, 64, 33-53.

Sturmbauer, C., Levinton, J.S. \& Christy, J., 1996: Molecular phylogeny analysis of fiddler crabs: test of the hypothesis of increasing behavioral complexity in evolution.- Proceedings of the National Academy of Sciences of the United States of America, 93, 10855-10857.

Trajano, E., 2005: Evolution of lineages. In: Encyclopedia of Caves (Eds. D.C. Culver \& W.B. White).- Elsevier, Amsterdam etc., pp. 230-234.

Verovnik, R, Sket, B. \& Trontelj, P., 2004: Phylogeography of subterranean and surface populations of water lice Asellus aquaticus (Crustacea: Isopoda).- Molecular Ecology, 13, 1519-1532.

Verovnik, R., Sket, B. \& Trontelj, P., 2005: The colonization of Europe by the freshwater crustacean Asellus aquaticus (Crustacea: Isopoda) proceeded from ancient refugia and was directed by habitat connectivity.- Molecular Ecology, 14, 4355-4369.

Verovnik, R., Sket, B., Prevorčnik, S. \& Trontelj, P., 2003: Random amplified polymorphic DNA diversity among surface and subterranean populations of Asellus aquaticus (Crustacea: Isopoda).- Genetica, 119, 155-165.

Zakšek, V., Sket, B. \& Trontelj, P., 2007: Phylogeny of the cave shrimp Troglocaris: evidence of a young connection between Balkans and Caucasus.- Molecular Phylogenetics and Evolution, 42, 223-235. 
